\title{
Turismo, moda e negócios no Maraponga Mart Moda em Fortaleza/CE
}

Tourism, business and fashion in Maraponga Mart Moda in Fortaleza/CE Turismo, negocios y moda en Maraponga Mart Moda en Fortaleza/CE http://dx.doi.org/10.18472/cvt.17n3.2017.1127

Priscila Medeiros Camelo 〈priscilamedeirosc@gmail.com > Universidade Estadual do Ceará (UECE), Fortaleza, CE, Brasil.

Luzia Neide Menezes T. Coriolano < luzianeidecoriolano@gmail.com > Universidade Estadual do Ceará (UECE), Fortaleza, CE, Brasil.

Cláudia Sousa Leitão 〈claudiasousaleitao@yahoo.com.br > Universidade Estadual do Ceará (UECE), Fortaleza, CE, Brasil.

CRONOLOGIA DO PROCESSO EDITORIAL

Recebimento do artigo: 13-out-2015

Aceite: 31-out-2017

FORMATO PARA CITAÇÃO DESTE ARTIGO

CAMELO, P. M.; CORIOLANO, L., N.; LEITÃO, C. S. Turismo, moda e negócios no Maraponga Mart Moda em Fortaleza/CE. Caderno Virtual de Turismo. Rio de Janeiro, v. 17, n. 3, p. 22-33, dez. 2017.

REALIZAÇÃO

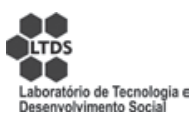

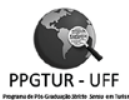

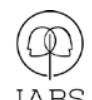

APOIO INSTITUCIONAL

EDIÇÃO

PATROCÍNIO

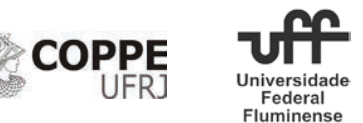

EDITORค 


\section{RESUMO}

Este artigo tem por objetivo analisar a contribuição da moda para o desenvolvimento do turismo de negócios em Fortaleza e o perfil dos compradores do shopping atacadista Maraponga Mart Moda. O turismo de negócios destaca-se na capital do Ceará como segmento em ascensão, proporcionando benefícios sociais e econômicos a Fortaleza, uma vez que contribui para o aumento do fluxo de turistas, gera renda e divulga a imagem do destino turístico. Fortaleza é um importante polo de moda e atrai revendedores de todo o Brasil. Optou-se pelo método fenomenológico, que investiga fenômenos humanos tais como são vivenciados e experimentados. Trata-se de um estudo de abordagem quanti-qualitativa, com base na revisão da literatura, e pesquisas documentais e de campo, com aplicação de questionários a compradores que frequentam o shopping. A análise dos dados ratifica a relevância dos negócios de moda em Fortaleza e a relação com o turismo fortalecendo-o. Conclui-se que o Maraponga Mart Moda incentiva a vinda de compradores atacadistas do País, movimenta a cadeia produtiva da moda e fortalece o turismo na capital cearense.

Palavras-chave: Turismo. Moda. Turismo de Negócios.

\section{ABSTRACT}

This paper aims to analyze the contributions given from fashion industry toward the development of business tourism in Fortaleza (Brazil) and the customer's profile at the Maraponga Mart Moda wholesaler mall. Business tourism stands out over Cearás capital city as a segment on the rise, providing social and economic benefits to Fortaleza, since it contributes to an increasing tourist traffic, creates income and publicizes the image of a tourist destination metropolis. Fortaleza is an important fashion hub and draws resellers from all over the country. The phenomenological method was taken as it researches human phenomena as those are lived and experienced. It is a quantitative-qualitative approach, based on literary review, documentary and field research, and through the preparation and application of questionnaires to buyers attending the wholesale mall. Data analysis endorses the relevance of fashion business to Fortaleza and its relevance in strengthening touristic activities. It is concluded that the Maraponga Mart Moda wholesaler mall encourages the forthcoming of resellers around the country, moving around the productive chain of fashion business and consolidates tourism activities in Cearás capital city.

Keywords: Tourism. Fashion. Business Tourism.

\section{RESUMEN}

Este artículo pretende analizar la contribución de sistemas para el desarrollo del turismo de negocios en Fortaleza y el perfil de los compradores del centro comercial mayorista Maraponga Mart Moda. El turismo de negocios se destaca en la capital de Ceará como segmento ascendente, proporcionando beneficios sociales y económicos a Fortaleza, ya que ayuda a aumentar el flujo de turistas, genera ingresos y promociona la imagen del destino turístico. Fortaleza es un importante polo de moda y atrae a comerciantes de todo Brasil. Optamos por el método fenomenológico, que investiga fenómenos humanos tal como son experimentados y probados. Se trata de un estudio de enfoque cuantitativo y cualitativo, basado en la investigación de campo, documental y revisión de literatura, investigaciones documentales y de campo, con el uso de cuestionarios con los compradores que asisten al centro. El análisis de los datos confirma la relevancia de los negocios de moda en Fortaleza y la relación con el turismo por fortalecerla. Se llegó a la conclusión que el Maraponga Mart Moda alienta la venida de compradores mayoristas del país, se mueve la cadena productiva de moda y fortalece el turismo en la Capital de Ceará.

Palavras clave: Turismo. Moda. Turismo de Negocios. 


\section{Introdução}

A atividade turística moderna amplia-se em razão das mudanças econômicas, sociais e culturais decorrentes da Revolução Industrial, no século XIX, quando a evolução dos meios de transporte e de comunicação acelera o modo capitalista de trabalhar, incentiva o lazer para ocupar o tempo livre, fazendo surgir o turismo - o lazer em viagem.

Desde então, o turismo passa a ser consumido e demandado de acordo com comportamentos específicos do consumidor, sugerindo segmentos diferenciados para atendimento às demandas. Para atender às exigências e expectativas diversificadas, as mudanças comportamentais atingem o mercado turístico sugerindo novas motivações de viagens. A necessidade de aventurar-se origina o turismo de aventura; o apreço por pratos saborosos, regionais ou típicos impulsiona o turismo gastronômico; a prática da fé movimenta o turismo religioso; o contato com a natureza motiva o ecoturismo; a busca da vivência com elementos significativos do patrimônio histórico-cultural origina o turismo cultural; a provisão de encontros de interesses econômicos, profissionais, comerciais, promocionais e sociais remete ao turismo de eventos e negócios.

O Brasil consolida-se como destino turístico, assim como Fortaleza, que além de ofertar o turismo de sol e praia, sendo uma cidade com rica oferta de rede hoteleira, restaurantes, gastronomia típica e vocação ao entretenimento, é lugar propício ao turismo de negócio. Tudo isso faz da cidade um dos destinos mais procurados no Brasil.

Fortaleza é um dos principais polos de moda do estado do Ceará e do País, destaca-se pela concentração de indústrias têxteis e de confecções, fato que a coloca no cenário nacional como centro dinâmico da moda. A cidade é destino de turismo de negócios de moda e atrai compradores atacadistas de diversos estados, reforçando os fluxos turísticos para Fortaleza, pois revendedores, lojistas e sacoleiros usufruem de serviços de hospedagem, alimentação, transporte e, após a realização dos negócios, dedicam o tempo livre ao lazer.

Os centros de compras em atacado crescem e se consolidam em Fortaleza, instigando às políticas públicas e privadas a se articularem para o fortalecimento das condições de hospitalidade da capital como polo de moda e de turismo de negócios. Dessa forma, Fortaleza passa a ser identificada como núcleo receptor turístico de sol e praia e destacado polo de moda do Brasil. A capital tem o turismo de negócios como forte segmento turístico, com possibilidade de maior crescimento e ampliação, uma vez que as viagens mobilizam o comércio local, geram rendas e movimentam a cadeia produtiva da moda e do turismo.

O turismo de sol e praia é sazonal, concentrando-se em altas estações que correspondem aos períodos de férias escolares. Para suprir essa sazonalidade, órgãos públicos formulam políticas de incentivo a outros segmentos turísticos na capital. Considerando essa realidade, o texto apresenta reflexões voltadas ao seguinte questionamento: como Fortaleza se configura no cenário nacional como destino turístico vinculado aos negócios da moda e como ocorre essa dinâmica? O texto tem como objetivo analisar a contribuição da moda para o desenvolvimento do turismo de negócios em Fortaleza e o perfil dos compradores atacadistas do shopping Maraponga Mart Moda. 


\section{METODOLOGIA}

No intuito de compreender a ligação entre turismo e moda, optou-se pelo método fenomenológico que envolve o estudo de fenômenos humanos, tais como são vivenciados e experimentados, considerando que a realidade não é única e que existem diversas interpretações e comunicações referentes a um mesmo fenômeno. A pesquisa fenomenológica considera a perspectiva filosófica e utiliza questões que exploram o significado da experiência. A realidade é apreendida pela coleta de dados junto a indivíduos que vivenciam o fenômeno. As informações coletadas indicam como o sujeito percebe o fenômeno, que se revela por meio da pesquisa. Dessa forma, a pesquisa fenomenológica livra-se de pressuposições, descreve os fenômenos com foco exclusivamente no fenômeno (CRESWELL, 1998; HUSSERL, 1990).

A pesquisa é respaldada na base teórica e institucional. Adquirida na revisão da literatura, adota procedimentos técnicos de coletas de dados na pesquisa de campo. Segundo Lakatos e Marconi (2006), a pesquisa de campo é utilizada com o objetivo de conseguir informações e/ou conhecimentos acerca de um problema, para o qual se procura resposta, proporcionando conhecimento da realidade pesquisada.

O levantamento de dados ocorre por meio da aplicação de questionário previamente estruturado, composto por questões com perguntas fechadas, que foram aplicadas aos compradores atacadistas do Maraponga Mart Moda, em abril de 2015. Questionário é uma técnica de pesquisa que envolve um conjunto de questões sistematicamente articuladas, que se destinam a levantar informações por parte dos sujeitos pesquisados, com vistas a conhecer a opinião destes sobre os assuntos em estudo, afirma Severino (2007). O grupo amostral da pesquisa abrange 375 (trezentos e setenta e cinco) compradores atacadistas ou turistas de negócios, vindos de diversas partes do País a Fortaleza para comprar no Maraponga Mart Moda.

\section{O turismo e a moda em Fortaleza - capital do Ceará}

O Ceará localiza-se na região Nordeste do Brasil, apresenta área de $148.825,6 \mathrm{~km}^{2}$ e é o $17^{\circ}$ estado brasileiro em termos de superfície territorial. É um dos estados do Brasil que mais se aproxima da Europa e da América do Norte, apresentando localização privilegiada (GOVERNO DO ESTADO DO CEARÁ, 2014), uma vez que se encontra próximo a importantes mercados emissores e receptores de turistas. Esse fato mostra-se como vantagem competitiva favorável ao Ceará, ante o cenário turístico internacional e nacional.

O Ceará é um lugar tropical, está entre as latitudes de $2^{\circ} 46^{\prime} 30^{\prime \prime}$ e $7^{\circ} 52^{\prime} 15^{\prime \prime}$, por isso exibe grande luminosidade, tratando-se de uma área privilegiada em relação à incidência de radiação solar e clima tropical, com temperatura que varia entre 28 e 33 graus Celsius, amenizada pelos ventos alísios, e 2.800 horas de sol por ano (CONTI, 1997). O turismo transforma a imagem do estado, associada à incidência de secas, em lugar ensolarado e de águas "calientes" propícias ao banho durante todo o ano. Essa imagem faz do Ceará um núcleo receptor do turismo de sol e praia, mas a proliferação de indústrias têxteis e de confecções, com diversidade de modelos e marcas, faz Fortaleza também se configurar como polo de moda nacional.

Com o propósito de ampliar e diversificar o turismo, o governo estadual implementa infraestruturas urbanas e turísticas a fim de fortalecer a atividade turística. Criam-se novas possibilidades para o turismo e, somado ao turismo de sol e praia, estimula-se o turismo de negócios, com instalação do Centro de Eventos 
do Ceará que é um dos centros de convenções mais modernos e bem equipados da América Latina, que abriga eventos, palestras, feiras, shows, congressos, workshops, exposições, seminários, eventos esportivos, entre outros, atentando-se para a diversidade de possibilidades econômicas que o turismo proporciona. Dessa maneira, além das belezas naturais, o Ceará qualifica-se para a atividade turística e passa a oferecer serviços de qualidade, adequando-se às novas demandas e necessidades turísticas.

Fortaleza, capital do Ceará, possui localização estratégica, atrativos e infraestrutura, sendo a principal porta de entrada de turistas para o estado. A cidade é banhada pelo Oceano Atlântico, com $34 \mathrm{~km}$ de praias. Fortaleza possui 2.571.896 habitantes estimados e é a quinta capital do Brasil em termos de população, ocupando área de 314,930 $\mathrm{km}^{2}$ e densidade demográfica de 7.786,44 (hab $\left./ \mathrm{km}^{2}\right)$, sendo uma das maiores do País (IBGE, 2014). É a maior cidade do estado e atua como portão de entrada oficial para turistas que almejam conhecer a região metropolitana ou demais municípios do Ceará, sendo um destino turístico de sol e praia consolidado.

Para que alcance melhores fluxos de visitantes o ano inteiro, sem sazonalidade, o estado investe no turismo de negócios. Assim, a capital passa a ser também referência em turismo de negócios, sendo a moda destaque, por meio dos negócios atacadistas que fortalecem os fluxos de visitantes.

Na opinião de Rodrigues (1999), o turismo de negócios passa a ser uma das molas propulsoras da atividade turística no século XXI e revela-se como um dos promissores segmentos do turismo, tendo o avanço das comunicações e o encurtamento das distâncias diminuído o tempo gasto nos deslocamentos e contribuído para a realização de negócios em nível nacional e global.

A pesquisa realizada pela Organização Mundial do Turismo (OMT, 2013) para o Anuário Estatístico do Turismo 2013, tendo como base o ano 2012, mostra que entre os motivos de viagens para o Brasil 46,8\% vieram por lazer e $25,3 \%$ por negócios, eventos e convenções. Já a demanda turística para Fortaleza, em 2013, foi de 3.141.406, sendo 2.895.646 turistas nacionais e 245.760 internacionais. Entre esses visitantes, 46,8\% das motivações das viagens foram por passeio; 18,9\% para visita a parentes/amigos; $20,9 \%$ para negócios/trabalho; 11,5\% para congressos/eventos e 1,9\% por outros motivos (SETUR-CE, 2014). Portanto, o turismo de negócios aparece logo após o motivo de lazer, demonstrando ser representativo na cidade.

Entre os teóricos que explicam o turismo de negócios estão Moraes (1999), que explica o turismo de negócios como o segmento em que a motivação da viagem é determinada pelos negócios; Beni (1998), que define turismo de negócios como o deslocamento de pessoas de negócios, portanto, turistas potenciais, que viajam para grandes centros cosmopolitas e empresariais, objetivando efetuar transações e atividades comerciais, profissionais e industriais; e Petrocchi (2004), que acrescenta que o turismo de negócio é o conjunto de atividades de viagem, hospedagem, alimentação e de lazer praticado por quem viaja a negócios referentes a diversos setores da atividade comercial ou industrial, ou para conhecer mercados, estabelecer contatos, vender ou comprar bens e serviços.

Aqueles que viajam para fazer compras de moda são denominados compradores atacadistas; são comerciantes, mas também turistas, uma vez que esses profissionais viajam para realizar compras, mas aproveitam para praticar lazer e usufruir dos restaurantes e lugares turísticos. Assim, a moda cearense se associa ao turismo. Em Fortaleza, essa atividade recorrente evidencia que a moda se alia ao turismo, pois motiva a vinda de visitantes interessados em geração de negócios.

As indústrias de confecções crescem em Fortaleza fazendo expandir shoppings atacadistas, feiras de moda e outlets na capital e entorno, o que fortalece o turismo e estimula fluxos de compradores atacadistas 
de diversos estados do Brasil. Nesse contexto, destaca-se o Shopping Maraponga Mart Moda, instalado em 1990, que atrai clientes de todo o País e dinamiza o turismo de negócios.

O Shopping Maraponga Mart Moda é considerado um dos mais completos shoppings atacadistas de moda do Norte-Nordeste do Brasil, atrai compradores desde o Sul do País até de Cabo Verde, na África, em busca de moda feminina, infantil, jeans, praia, íntima, bolsas, calçados, acessórios, óculos, artigos para loja e perfumaria. São 300 marcas de vários segmentos (ANUÁRIO DA MODA DO CEARÁ, 2013, p.76).

Em Fortaleza, o Maraponga Mart Moda conta com uma área de $45 \mathrm{mil} \mathrm{m}^{2}$ que abriga lojas, restaurantes, lounge para a realização de eventos e um hotel, abrigando compradores atacadistas vindos de diversos estados para comprar nas indústrias de confecções do Ceará. É válido ressaltar que a moda cearense tem reflexo na atividade turística, uma vez que as pessoas que negociam e vêm a Fortaleza usufruem de serviços de hospedagem, alimentação, transporte e aproveitam o tempo livre na cidade para a diversão e o lazer.

\title{
A cadeia produtiva da moda
}

Moda é um termo que vem do latim modus, e nas línguas latinas, caso do português, significa "modo", "maneira" (BRAGA, 2006). É oportuno ressaltar que a moda não se limita ao universo de roupas, trata-se de uma expressão abrangente e transversal, que está presente na arquitetura, música, literatura, design e turismo. Svendsen (2010) afirma que:

A moda está relacionada a diversas áreas de interesse, como vestuário, corpo, consumo, identidade e arte. Pretendo me concentrar principalmente na moda de vestuário embora existam muitos outros tipos. De fato, ela não é só uma questão de roupas e seria melhor considerá-la um mecanismo ou uma ideologia que se aplica a quase todas as áreas concebíveis do mundo moderno, do final do período medieval em diante (SVENDSEN, 2010, p. 12).

O conhecimento da cadeia produtiva faz-se imprescindível para aprimoramento da atividade econômica, pois abrange desde a produção da matéria-prima até a comercialização do produto final da moda. A cadeia produtiva da moda engloba atividades ligadas à indústria têxtil e de confecção, envolvendo diversos setores produtivos, incluindo as atividades manufatureiras até a distribuição do produto final. Há, por trás de cada peça de roupa confeccionada, várias etapas que são seguidas para que o produto chegue ao destino final: o consumidor. A moda, portanto, é resultado de uma longa e integrada cadeia de atividades. Haguenauer et al. (2001) explicam a cadeia produtiva assim:

\begin{abstract}
É um conjunto de atividades, nas diversas etapas de processamento ou montagem, que transforma matérias-primas básicas em produtos finais. Em uma estrutura industrial razoavelmente desenvolvida é praticamente impossível a delimitação das cadeias produtivas no sentido estrito, dada a interdependência geral das atividades, além da possibilidade de substituição de insumos [...]. Em cada cadeia produtiva encontram-se indústrias estreitamente relacionadas por compras e vendas correntes, constituindo os principais mercados e/ou fornecedores das demais atividades participantes. (HAGUENAUER et al., 2001, p. 6).
\end{abstract}

A cadeia da moda, ao envolver diversas etapas produtivas inter-relacionadas, configura-se como uma filière ${ }^{1}$, onde cada fase apresenta processos, especificidades e auxilia o desenvolvimento da fase seguinte (RECH 2006; RECH, 2008; RUTHSCHILLING, 2009). A cadeia produtiva da moda envolve as seguintes etapas: produção da matéria-prima, fiação, tecelagem, acabamento, confecção e mercado, onde o produto final de cada etapa torna-se matéria-prima da etapa seguinte.

1 Termo de origem francesa que apresenta o significado de fileira, ou seja, uma sequência de atividades empresariais que conduzem a uma sucessiva transformação de bens, do estado bruto ao acabado ou designado ao consumo (RECH, 2006, p.19). 
A produção de matéria-prima é a primeira fase da cadeia produtiva da moda e corresponde à etapa de produção das fibras têxteis, que têm origem vegetal, animal ou química. Essas fibras são transformadas em fios na etapa de fiação e seguem para a tecelagem ou malharia, transformando-se em tecidos. Estes, posteriormente, passam por acabamentos, a fim de que se tornem adequados à produção de roupas. A confecção envolve o processo de criação e produção da peça. Já o mercado, é a etapa que se encarrega da distribuição e comercialização das peças confeccionadas.

Na cadeia da moda, afirma Rech (2006), estão inseridos outros setores que não foram listados, mas que participam e são essenciais ao fluxo das etapas, alguns vinculados à indústria química e de bens de capital, dada a alta demanda da indústria têxtil e de confeç̧ão por equipamentos e maquinários. Ademais, operam também na cadeia da moda, serviços intermediários, como suporte mecânico-técnico, empresas de desenvolvimento de software, agências de publicidade, editoras de moda, entre outros. Pelo exposto, verifica-se que a indústria da moda se associa ao turismo apresentando grande importância para Fortaleza, atraindo grandes negócios do mundo moderno para a metrópole, ampliando os impactos socioeconômicos pelo efeito multiplicador que essas atividades desencadeiam.

\section{0 algodão e os negócios da moda no Ceará}

O sertão do Nordeste teve ocupação no início no século XVII, com o ciclo do gado e, posteriormente, com o ciclo do algodão. Este passou a ser o principal produto local e de troca (escambo), servindo também como moeda por meio de nimbos, que correspondia a uma determinada quantidade de fios de algodão em rolos ou novelos de fios. $\mathrm{O}$ algodão cearense foi cultivado principalmente por duas tribos indígenas: Cariri e Tarairiú, que usando um tear artesanal confeccionam redes e outros utensílios. Desfrutando da habilidade dos indígenas, os jesuítas passaram a exercer atividades educativas nos aldeamentos ensinando técnicas de fiação e tecelagem para os índios do Ceará, conforme Porto Alegre (1992) e Aragão (2002).

No Ceará, a abundância de algodão estocado somado a condições especiais, como existência de uma classe operária, principalmente em Fortaleza, que se torna força de trabalho para a indústria têxtil local, a aquisição de edificações próprias e a importação de maquinários especializados vindo da Inglaterra, são fatores que contribuem para a consolidação da indústria têxtil no estado. Entre 1882 e 1895, seis unidades fabris se instalam no Ceará. São elas: Fábrica Progresso (1883), Cia. Fábrica de Tecidos União Comercial (1891), Cia. Fabril Cearense de Meias (1891), Santa Thereza (1893), Fábrica Ceará Industrial (1895) e Sobral (1895), sendo todas beneficiadas por incentivos governamentais, para fomento da indústria local, e verbas governamentais destinadas a combater os efeitos da seca no estado (ANUÁRIO DA MODA DO CEARÁ, 2013).

Assim, a indústria de modo geral e, em especial, a têxtil, é instalada tardiamente no Ceará, se comparado com alguns estados do Nordeste, que investiram na industrialização já no início do século XIX. Apenas em 1883 veio a funcionar a primeira fábrica têxtil cearense, a Pompeu \& Irmãos. A industrialização no estado viabilizou, sobretudo, a modernização do Ceará, o domínio de novas técnicas de produção e a formação da classe operária assalariada, que passou a residir em Fortaleza, município onde houve maior incidência de industrialização (ARAGÃO, 2002). A industrialização foi importante para o Ceará devido à grande produção do algodão e à necessidade de se absorver o contingente de mão de obra que se encontrava desalojada com as secas.

Parente (1958) justifica que o primeiro surto industrial do Ceará foi decorrente do acúmulo de algodão estocado que estimulou a fabricação de fios e de tecidos. No entanto, ressalta o autor que as fábricas têxteis 
não chegaram a ser significativas nos mercados consumidores do algodão, estando destinadas ao mercado nacional. Além disso, a inconstância da produção algodoeira no Ceará, devido às secas, pragas e doenças, prejudicava a colheita, atrapalhando o abastecimento das indústrias têxteis do estado.

No entanto, a moda do Ceará não se relaciona unicamente à indústria de algodão, mas também à renda, bordados, labirinto, renascença, crochê de linha fina, casa de abelha e richelieu. Estes são elementos que caracterizam a moda cearense, sendo também relacionados à região Nordeste do Brasil, com o uso difundido em diversos países. Porém, apesar da valorização do artesanato local, poucos profissionais conseguem transformá-lo em moda. Castilho e Garcia (2001) acreditam que o Brasil está sendo descoberto e que é o momento de investir com qualidade na moda local.

O artesanato passa a ser valorizado por profissionais da moda local, sendo considerado um diferencial competitivo. Verifica-se mudança na concepção do uso do artesanato associado à moda, a partir do momento que os trabalhos manuais, populares no Ceará, passam a compor coleções de estilistas, que buscam inovar no mercado. No cenário do mercado globalizado, faz-se necessário buscar e construir diferenças que contribuam para a competitividade. Desse modo, o artesanato atrela-se à moda cearense enriquecendo-a.

A indústria de confecção é uma das principais atividades industriais do Nordeste e caracteriza-se pela heterogeneidade de escala, abrangendo micros, pequenas, médias e grandes empresas, com participação predominante das micro e pequenas empresas. A diversidade de escala das empresas contribui para que a qualidade dos produtos seja diferenciada e que haja uma heterogeneidade produtiva e tecnológica entre empresas de maior e menor porte, dificultando assim a análise do polo de moda do Ceará, por tratar-se de um cenário com realidades antagônicas e diversas.

Em relação à distribuição espacial do setor de vestuário do Ceará, há dez municípios do estado considerados mais representativos, detendo mais de 90\% dos estabelecimentos. Desses municípios, apenas três não estão inseridos na Região Metropolitana de Fortaleza: Juazeiro do Norte, Sobral e Frecheirinha. Fortaleza detém o primeiro lugar, com 2.430 estabelecimentos; Maracanaú em segundo, com 118 estabelecimentos; Juazeiro do Norte em terceiro, com 80 estabelecimentos; Caucaia em quarto, com 78 estabelecimentos; Maranguape em quinto, com 67 estabelecimentos; Aquiraz em sexto, com 32 estabelecimentos; Pacatuba em sétimo, com 31 estabelecimentos; Sobral em oitavo, com também 31 estabelecimentos; Pacajus em nono, com 25 estabelecimentos e Frecheirinha em décimo, com 24 estabelecimentos (INDI, 2013). Os dados demonstram que Fortaleza é a cidade que mais se destaca na moda cearense, sendo forte na cidade a presença de confecções e indústrias têxteis.

Com a intenção de desenvolver a moda local, o estado passa a investir em instituições formadoras para qualificar e aperfeiçoar profissionais, a fim de manter as empresas cearenses competitivas, conservando a imagem do Ceará como polo de moda do Brasil.

\section{A formação da força de trabalho em moda em Fortaleza}

A profissão de design de moda (fashion designer) é recente, típica da sociedade moderna ocidental. É atribuído ao inglês Charles Frederick Worth o papel de ter dado origem a um novo campo de atuação: o criador de moda. Worth elevou a posição de costureiro para criador de moda, a partir do momento que alinhou negócio de moda à criação de moda (KELLER, 2007). Assim, o criador de moda passou a ser 
um profissional fundamental para a indústria de moda. São várias as habilidades requeridas para esse profissional, tais como: habilidade básica de desenho, conhecimento técnico da construção da roupa, familiaridade com os insumos da produção (tecidos e aviamentos), domínio técnico e operacional do processo de fabricação de roupas e capacidade criativa e inovadora.

No Brasil a estruturação de cursos de moda surge no momento em que a indústria têxtil e de confecção passa por séria crise. O setor de moda, diante de um cenário crítico, marcado por alta inflação, abertura do mercado para as importações e instauração do Plano Collor, que comprometeu o consumo dos brasileiros, busca mudanças e medidas urgentes para qualificar a produção nacional.

A cidade de São Paulo foi pioneira na criação de cursos de moda na Universidade Anhembi Morumbi e Faculdade Santa Marcelina, mas logo em seguida houve uma profusão de cursos no meio acadêmico, em todo o País. Existem cursos superiores de moda em vários estados do Brasil, como na Universidade Federal do Ceará.

No Brasil cresce a oferta de cursos lato sensu na área de moda, com a finalidade de capacitar profissionais. De acordo com Pires (2002, p. 5), os cursos surgem porque as condições materiais das cidades e a produção têxtil estão consolidadas e sua população comprometida com esse processo, a exemplo de São Paulo, Belo Horizonte, Blumenau, Jaraguá do Sul, Londrina, Maringá e Ceará. Dessa forma, a demanda do mercado foi fator determinante no estabelecimento dos cursos universitários de design de moda.

Em 1993 é criado o primeiro curso de graduação em Estilismo e Moda em uma Universidade Federal brasileira, a Universidade Federal do Ceará (UFC), como extensão da Faculdade de Economia Doméstica. Em 2002, o curso foi reconhecido pelo Ministério da Educação como bacharelado, ofertando 40 vagas por ano. Atendendo à solicitação do Ministério da Educação, em 2010, o curso passa a ser chamado de Design de Moda, tendo projeto pedagógico e grade curricular reformulados, ampliando-se também o número de vagas anuais, que passou de 40 para 60 , com a finalidade de atender à demanda crescente. Após o pioneirismo da UFC, outras instituições passaram a ofertar curso de graduação na área de moda.

Ainda em 2003 é criada a Faculdade Católica do Ceará que entre os cursos ofertados disponibiliza o de Design de Moda tecnólogo, com duração de dois anos e meio para formar profissionais qualificados para trabalhar com a indústria têxtil e de confecção, coordenação de moda e de confecções, além de consultoria e empreendedorismo. No entanto, em 2013 a faculdade é fechada, encerrando as atividades educacionais. Todavia, a capital cearense conta com cursos de moda nas seguintes Faculdades, com graduação tecnológica: Faculdade Integrada do Ceará (FIC), Faculdades Nordeste (Fanor), Faculdade Ateneu (Fate) e, ainda em 2013, o Ceará ganha mais um curso de moda, na Universidade de Fortaleza (Unifor) (ANUÁRIO DA MODA DO CEARÁ, 2014).

É imprescindível, portanto, que criadores de moda busquem subsídios para aprimorar o desenvolvimento do produto nacional para atender às demandas do setor e dos consumidores. Embora seja possível contabilizar um grande número de profissionais autodidatas no País, alguns reconhecidos até internacionalmente, enfatiza-se a importância da profissionalização e capacitação da indústria têxtil e de confecção para o crescimento do mercado, em termos quantitativo e qualitativo. Feghali e Dwyer (2006) compartilham da mesma ideia ao citarem que fatores como aprimoramento e especialização da força de trabalho é que criam facilidades para que a indústria brasileira de moda fique em sintonia com os padrões técnicos exigidos pelo mercado e ganhe competitividade em relação aos concorrentes internacionais, equilibrando gastos e lucros, preço e qualidade. 
Considerando a ascensão da área de moda no Ceará, mais especificamente em Fortaleza, verifica-se que as instituições de ensino libertam a moda cearense do amadorismo, formando profissionais qualificados para assumirem a direção criativa e de estilo das marcas locais. Dessa forma, a moda passa a ser encarada com seriedade, viabilizando a expansão dos negócios de moda na cidade.

\section{Perfil e comportamento dos compradores do shopping Maraponga Mart Moda}

O perfil e o comportamento dos compradores atacadistas do shopping Maraponga Mart Moda, de acordo com a pesquisa de campo realizada, consideram as seguintes variáveis: gênero, local de residência, idade, nível de rendimento médio mensal, fatores que motivam a compra da moda em Fortaleza, impressão geral de Fortaleza enquanto destino para compras em atacado e participação em atividades de lazer durante período de estada na cidade. No que se refere ao gênero, a amostra total revela que a maioria dos compradores atacadistas são mulheres, sendo $79 \%$ dos visitantes do gênero feminino e $21 \%$ do gênero masculino.

Em relação à residência dos compradores, verificou-se que a maioria dos compradores atacadistas visitantes são das regiões Nordeste e Norte, sendo essas regiões os principais polos emissivos de compradores atacadistas do Maraponga Mart Moda. Dos 375 pesquisados, 258 residem no Nordeste, 105 no Norte, 9 no Sudeste, 1 no Sul e 2 no Centro-Oeste. Já em relação à idade dos compradores atacadistas $0,3 \%$ tem até 18 anos; $2,7 \%$ têm de 18 a 24 anos; $22,7 \%$ de 25 a 34 anos; $42,1 \%$ de 35 a 44 anos; $21,9 \%$ de 45 a 54 anos; $8,8 \%$ de 55 a 64 anos e 1,6\% acima de 65 anos.

A renda é um aspecto importante na composição do perfil desse público e verificou-se que, em relação à renda mensal dos compradores atacadistas, 2,4\% recebem até um salário mínimo; 29,9\% de 1 até 3 salários mínimos; $34,7 \%$ de 3 até 5 salários mínimos; 26,4\% de 5 até 7 salários mínimos; $4,5 \%$ de 7 a 10 salários mínimos; $1,3 \%$ acima de 10 salários mínimos e $0,8 \%$ não informaram, considerando que o valor do salário mínimo nacional, em 2015, é de R $\$ 788,00$ (setecentos e oitenta e oito reais).

Sobre a imagem de Fortaleza, enquanto destino para compras em atacado, dos 375 inquiridos, 52,5\% têm uma boa impressão sobre o polo de moda de Fortaleza; 38,7\% afirmam ser Fortaleza uma excelente cidade para compras em atacado; 8,3\% consideram o destino regular e apenas $0,5 \%$ ruim. E entre os fatores que motivam os compradores atacadistas a viajarem para comprar moda em Fortaleza, verificouse que $41,1 \%$ dos inquiridos se motivam a comprar em Fortaleza devido à qualidade das peças/marcas; 40,3\% foram atraídos pela variedade de produtos oferecidos na cidade; $17,1 \%$ são atraídos pelo preço; $0,5 \%$ pela tradição da cidade como polo de moda e $1,1 \%$ por outros motivos.

No que concerne às atividades turísticas realizadas em Fortaleza, durante o período de estada na cidade, $84,9 \%$ dos inquiridos participaram de atividades turísticas e gostam e apenas $15,2 \%$ dos entrevistados afirmaram não conseguir ter tempo para outra atividade, além das compras.

\section{CONCLUSÃO}

Pode-se afirmar que o Maraponga Mart Moda dinamiza e mobiliza diversos fluxos, desde compradores atacadistas, empreendedores e sacoleiros, movimentando duas cadeias produtivas: a da moda e a do 
turismo. Assim, o shopping é um agente fomentador turístico da cidade, gera recursos para a capital, sendo um empreendimento significativo e relevante para o turismo de negócios local.

Pode-se afirmar que os espaços de negócios de moda em atacado, sobretudo o Maraponga Mart Moda, na cidade de Fortaleza, cresce e faz crescer o turismo local. Por meio da pesquisa, infere-se que o empreendimento tem uma atração geográfica ainda restrita, uma vez que o número de compradores de outras regiões do Brasil mostra-se ainda incipiente, ao comparar-se com os das regiões Nordeste e Norte.

O fato de Fortaleza ser um polo de moda, reunir grande número de fábricas, marcas e centros comerciais, faz com que a cidade torne-se alvo de compradores atacadistas de todo o Brasil que buscam mercadorias, no comércio atacadista local, para revender nas cidades de origem. Assim, o turismo de negócios mostrase como aliado para dinamizar tanto a cadeia produtiva da moda como a de turismo, uma vez que a vinda de compradores atacadistas mobiliza tanto a indústria de confecções de Fortaleza como o setor do turismo, envolvendo serviços de hospedagem, transporte, alimentação, lazer e entretenimento.

\section{REFERÊNCIAS}

ANUÁRIO DA MODA DO CEARÁ. Diário do Nordeste, Fortaleza, v. 2012|2013, 2013.

ANUÁRIO DA MODA DO CEARÁ. Diário do Nordeste, Fortaleza, v. 2013|2014, 2014.

ARAGÃO, E. F. (Org.) [et al.]. 0 fiar e o tecer: 120 anos da indústria têxtil no Ceará. Fortaleza: SINDITÊXTIL/FIEC, 2002.

BENI, M. C. Análise Estrutural do Turismo. São Paulo: Senac São Paulo, 1998.

BRAGA, J. Reflexões sobre Moda, v. 3. São Paulo: Anhembi Morumbi, 2006.

CASTILHO, K.; GARCIA, C. Moda Brasil: fragmentos de um vestir tropical. São Paulo: Anhembi Morumbi, 2001. 157p.

CONTI, J. B. A natureza nos caminhos do turismo. In: RODRIGUES, A. B. (Org.) Turismo e ambiente: reflexões e propostas. São Paulo: Hucitec, 1997.

CRESWELL, J. Qualitative Inquiry and Research Design: choosing among five traditions. Thousand Oaks, CA: Sage Publications, 1998.

FEGHALI, M. K.; DWYER, D. As Engrenagens da Moda. Rio de Janeiro: Senac, 2006.

GOVERNO DO ESTADO DO CEARÁ. Ceará, viva essa alegria. Disponível em: 〈http://www.ceara.gov.br/ ceara-viva-essa-alegria〉. Acesso em: 11 jul. 2014.

hAgUenaVer, L.; BAHIA, L. D.; CASTRO, P. F.; RIBEIRO, M. B. Evolução das Cadeias Produtivas Brasileiras na Década de 90. Texto para discussão $n^{\circ}$ 786, IPEA, abril, 2001.

HUSSERL, E. A ideia da Fenomenologia. Lisboa: Edições 70, 1990.

INSTITUTO BRASILEIRO DE GEOGRAFIA E ESTATÍSTICA. Cidades: Ceará - Fortaleza. Disponível em: 〈http://www.cidades.ibge.gov.br/xtras/perfil.php?lang\&codmun=230440〉. Acesso em: 30 nov. 2014. 
INSTITUTO DE DESENVOLVIMENTO INDUSTRIAL DO CEARÁ. Perfil Setorial Vestuário 2013. Disponível em: 〈http://www.sfiec.org.br/portalv2/sites/indi/files/files/Estudo\%20Setorial\%2oVestuario\%20 -\%20FINAL.pdf $\rangle$. Acesso em: 10 jan. 2014.

KELLER, P. F. O trabalho imaterial do estilista, a produção de moda e a produção de roupa. In: ENCONTRO ANUAL DA ASSOCIAÇÃO NACIONAL DE PÓS-GRADUAÇÃO E PESQUISA EM CIÊNCIAS SOCIAIS, 31., 2007, Caxambu. Anais... Caxambu: ANPOCS, 2007. p. 1-29. Disponivel em: 〈http://www.anpocs.com/index. php/papers-31-encontro/st-7/st34-1/3167-paulokeller-o-trabalho/file>. Acesso em: 10 jan. 2014.

LAKATOS, E. M.; MARCONI, M. A. Técnicas de Pesquisa. 4. ed. São Paulo: Atlas, 2006.

MORAES, C. Turismo - segmentação de mercado: um estudo introdutório. In: ANSARAH, M. (Org.). Turismo - segmentação de mercado. São Paulo: Futura, 1999. p. 13-33.

ORGANIZAÇÃO MUNDIAL DO TURISMO. Anuário Estatístico de Turismo - 2013. Disponível em: 〈http:// www.dadosefatos.turismo.gov.br/export/sites/default/dadosefatos/anuario/downloads_anuario/ Anuario_Estatistico_de_Turismo_-_2013_-_Ano_base_2012_-_Versao_dez.pdf. . Acesso em: 20 jul. 2014.

PARENTE, E. G. Relatório do Departamento de Expansão Econômica do Ceará - 1957. Fortaleza: DEEC, 1958.

PETROCCHI, M. Marketing para destinos turísticos: planejamento e gestão. São Paulo: Futura, 2004.

PIRES, D. B. A história dos cursos de design de moda no Brasil. In: CONGRESSO BRASILEIRO DE PESQUISA E DESENVOLVIMENTO EM DESIGN, 5., 2002, Brasília. Anais... Brasília: Fundação Universidade de Brasília, 2002. p. 1935-1943.

PORTO ALEGRE, M. S. Fontes inéditas para a história indígena no Ceará. Fortaleza: Universidade Federal do Ceará, 1992 (Caderno do NEPS).

RECH, S. R. Cadeia Produtiva da Moda: um modelo conceitual de análise da competitividade no elo confecção. 301f. 2006. Tese (Doutorado em Engenharia da Produção) - Universidade Federal de Santa Catarina, Florianópolis, 2006.

. Estrutura da cadeia produtiva da moda. Modapalavra e-periódico, Florianópolis, ano 1, n. 1, jan./jul. 2008, p. 7-20.

RODRIGUES, A. B. Lugar, não lugar e realidade virtual no turismo globalizado. In: RODRIGUES, A. B. (Org.). Turismo e Espaço: rumo a um conhecimento transdisciplinar. 2. ed. São Paulo: Hucitec, 1999. p. 25-36.

RÜTHSCHILLING, A. A. Design de Vestuário de Moda Contemporânea: criação versus produção. 159f. 2009. Dissertação (Mestrado em Design e Marketing) - Escola de Engenharia, Universidade do Minho, Braga/Portugal, 2009.

SETUR-CE. SECRETARIA DO TURISMO DO ESTADO DO CEARÁ. Indicadores Turísticos 1995/2013. Disponível em: 〈http://www.setur.ce.gov.br/categoria1/estudos-e-pesquisas/Indicadores\%202014. pdf>. Acesso em: 05 mar. 2014.

SEVERINO, A. J. Metodologia do trabalho científico. 23. ed. rev. e atual. São Paulo: Cortez, 2007.

SVENDSEN, L. Moda: uma filosofia. Rio de Janeiro: Zahar, 2010. 